\title{
Intelligence, Creativity and Fantasy
}

Edited ByMário S. Ming Kong, Maria do Rosário Monteiro, Maria João Pereira Neto Edition 1st Edition

First Published 2019

eBook Published 30 September 2019

Pub. location London

Imprint CRC Press

DOIhttps://doi.org/10.1201/9780429297755

Pages 600 pages

eBook ISBN 9780429297755

SubjectsArts, Built Environment, Humanities

Disponível para compra em: https://www.crcpress.com/Intelligence-Creativity-and-

Fantasy-Proceedings-of-the-5th-International/Kong-Monteiro-

Neto/p/book/9780367277192\#googlePreviewContainer

\section{Part I Intelligence, creativity and fantasy}

The creativity code

M. du Sautoy

The intelligence of fiction

F. Lavocat

The presence of metaphysical symbolism in architectural formation of Armenia early and medieval spiritual sites

A. Shatvoryan

Fantasies of space and time

D. Fimi

Traces of a recreated reality: Rafael Bordalo Pinheiro's busts of Pai Paulino M. do R. Pimentel

Political fiction or the art of the deal

R. Zink

\section{Part II Architecture/urbanism/design}

"Through the rabbit hole": Intelligence creativity and fantasy in architectural composition

M.S.M. Kong 
Creativity and beauty in art and science today: A basis for discussion of a possible future architecture

C.G. Gonçalves

Notes on illusion: Ideation as an instrument for a spatial intelligence of architecture F. Oliveira

'The open work': Inter-relations between science and art

A.M. Feliciano

UOVO-EGG-OEUF-OVO: From the origins of the world to a creative objective R. Maddaluno

Towards a meta-Baroque: Imagining a "fantastic reality"

M.J. Soares

Stolen characters against an enclosure of the imagination

D. Jesus

Developing creative approaches in architectural education

I. Tarasova

Fantasy and creativity of the Azuchi-Momoyama period Japanese tea architecture A.P. Higashino

From fantasy to experimentation: The one-to-one scale in architecture exhibitions A. Neiva

Architecture and cinema: The tower as both scenario and protagonist

E. Kuchpil \&A. Pimentel dos Santos

Fictional movement on the NY's Guggenheim ramp

S. Paiva de Sousa \& M. Baptista-Bastos

Gottfried Böhm's creativity: Architecture as a sculpture made of concrete

A. Serafin

Intelligence, creativity and fantasy in Bernard Tschumi's Glass Video Gallery: Inbetween translucency, transgression and interaction

A. Vasconcelos

From the intensity to the essence: Fantasy and architectural creativity between the Neorealism and the Third Modernism in Portugal

M. Baptista-Bastos \& S. Paiva de Sousa

Paper as a flexible alternative applied to the Dom-Ino System: From Le Corbusier to Shigeru Ban

A. Nogueira \& M.S.M. Kong 
The internationalisation of Álvaro Siza and the myth of the traditional and conservative architect

J. Nunes

The fantasy of reality: On the design drawings of Álvaro Siza Vieira

J.M.C. Duarte

The "good taste": When patterns restrict creativity

G.M. de Carvalho

Creativity and pragmatism: A practical example of a project

C.R. Castro \& M.S.M. Kong

Towards a more intelligent dwelling: The quest for versatility in the design of the contemporary home

H.L. Farias

The house as a mirror and support of identity: Reflections for a more conscious and subjective inhabiting

A. Santos Leite

Architecture stories in the construction of children's spatial conscience

M. Louro

From fantasy to reality: Adaptive reuse for flour mills in Venice

S. Palomares Alarcón

The ruined fantasies of intelligent minds: 'The Nobel's town' and neglected Swedish heritage in St. Petersburg

I. Seits

World-in-spheres: A cartographic expedition through the spherical world of Peter Sloterdijk

F.H. Brum de Almeida, G.H. Rosa Querne \& L. de M. Reitz

From international context to Portuguese urban planning: Creativity on mechanical aesthetics in Planos Gerais de Urbanização

J. Cabral Dias

"Fantastic" colonial cities: Portuguese colonial utopia

A. Ramos

Fantasy and reality belong together; multidimensional thinking to innovate the creative process

J. Silveira Dias \& D. Loução

Creativity and intelligent research in design: The use of quasi-experience

F. Moreira da Silva 
Sustainability through design creativity

\section{A. Moreira da Silva}

Design skills and craftwork culture in scenic design for theatre

L. Soares, R.A. Almendra, E. Aparo \& F. Moreira da Silva

Foot haptic perception in hospital wayfinding

M. de A. Borges

Methodology for colour planning in urban furniture: Laje, a case study

M. Gamito \& J. Sousa

Fashion design and productive thinking: Pragmatical approaches to creativity

L. Ferrão \& G. Sousa

\section{Part III Arts}

Fantasy, creativity and proportions: Spiral representations in culture and art T. Lousa \& J. Mikosz

The creative daemon ( $\delta \alpha i \mu \omega v)$ and the hyper-intellection of art J. Pereira de Matos

The creation through listening: Expression, intelligence, inspiration and wisdom S.C. Yan \&A.L.M.M. Rodrigues

Art and mind set: Neuroscience and education in the life project

C. Accetta

The creativity of artistic appropriation and the copyright

G. Horváth

Creativity through destruction in the genesis of artist's books
A. Canau

Aldo Rossi's Teatrino

Fernando J. Ribeiro

The torrent of art, the rooms of art. The Fiumara d'Arte and Atelier sul Mare in Sicily

S. Centineo

Considerations on the colours of Pompeii walls

M.J. Durão

Pictorial (re-) creations: From the fourth Centenary of India (1898) to Expo'98

M.J. Castro 
Creativity and the observer

\section{A.L.M.M. Rodrigues}

Drawing in architecture: Exercising the creativity of thinking architectural space A.R. Ortega \& S. Weihermann

\section{Part IV Humanities}

The love of the one for the many and the many for the one D. Swartz

A Mesopotamian notion of intelligence and creativity: The ingenious nature of Enki/Ea I.G. de Almeida

The legend of Sardanapalus: From ancient Assyria to European stages and screens M. de F. Rosa

Fantasy, cryptozoology and/or reality: Interconnected stories of mythological creatures and marine mammals

C. Brito

To ponder the pathology of power in the early modern Era: Creativity and intelligence in the political theory and practice reflected in emblems and iconological programs M.L.G. da Cruz

From the ineptitude to a higher capability: The Jesuits and the formation of a Christian community in Brazil and Japan (16th-century)

M.A. Boscariol

Creativity in the 16th-century representation of King Sebastião's in the Battle of Ksarel-Kebir

\section{A.P. Avelar}

Intelligence and creativity at the service of the Society of Jesus in 16th century Japan: The contribution of Father Luís Fróis

H. Resende

A science of the probable; epistemological inventiveness according to Diderot L.M.A.V. Bernardo

The gaze of death or modern adventures of the imagination in three acts

S. Wróbel

The railways of the Begum's Fortune by Jules Verne and André Laurie F. de L. Lourencetti 
On Hesse's Der Steppenwolf: How creatively actual a modern literary artwork can lively be?

F. Ribeiro

Creativity in H.G.Wells: Imagining the role of miracles in a secular society

L. Sampaio da Silva

On stories: Tolkien and fictional worlds

M. do R. Monteiro

Victorious nature in Anglo-Saxon England and fantasy Middle-earth

\section{A. Cossío}

Tree and forest models in Victorian/Edwardian fantasy: MacDonald, Morris and Grahame as triggers of J. R. R. Tolkien's Creativity
A. Cossío

From Tolkien's British Middle-earth to King's AmericanWest Mid-World R. Montero-Gilete

The final frontier: Fictional explorations of the borders of nature and fantasy in early twentieth-century imaginative literature

M. Simonson

The cure for death: Fantasies of longevity and immortality in speculative fiction T. Botelho

Upgraded fantasy: Recreating SF film

I. Borbely

Healing through storytelling: Myth and fantasy in Tomm Moore's Song of the Sea

A. Varandas

Between reality and fantasy; a reading of Katherine Vaz' "My Hunt for King Sebastião" M. Avelar

Intelligence, creativity and fantasy in Baltasar and Blimunda, by José Saramago L.S. Loureiro

Intelligence for obedience and creativity for subversion: Reading António Ladeira's $O s$ Monociclistas (2018) and Seis Drones (2018)

M. Rendeiro

Literary creativity and political debate. The case of African journals Mensagem and Notícias do Imbondeiro

N. Alfieri

Creativity and innovation in Cante from the Estado Novo to the present E.M. Raposo 
From rap to literature: Creativity as a strategy of resistance in Portugal through the works by Telma Tvon

F. Lupati

\section{Part V Social sciences}

Creativity, Utopia and Eternity at the Francke Foundations in Halle: Art between image politics and cultural memory

K. Groop

Harriet Martineau, John H. Bridges, and the sociological imagination

M.Wilson

Form and function regulating creativity and facilitating imagination: Literary excursions in the diary of my great-grandfather

J. Dahlbacka

Translanguaging as a creative and enriching practice

R. Seredy'nska-Abou Eid

\section{Part VI Sciences/technologies}

Intelligence, innovation, fantasy and heart: The Portuguese engineers of the nineteenth and early twentieth centuries

A. Cardoso de Matos

The introduction of new construction materials and the teaching of engineering based on technical intelligence: The role of Antão Almeida Garrett

M. da L. Sampaio

A relationship between typography, designers and users to build a creative experience in the digital culture

E. Napoleão, G. Braviano, P.M.R. Amado \& M.J. Baldessar

The fantasy of the natural/cultural elements as symbolic tourist attractions through senses and technology

A. Pereira Neto

Remediation and metaphor: Gamifying teaching programming

D. Maestri \& L.M. Fadel

Pokémon Go: The embedded fantasy

G.H.C. de Faria, L.M. Fadel \& C.E.V. Vaz

Crowdsourcing: An intelligent and creative way for information access

L.C. Borges \&A.M.D. da Silva 
Comparative analysis of the luminous performance of fenestration with Japanese paper and glazing with a polymeric film in meditation rooms

M.B. Cruz, J. Pereira, M. da G. Gomes \& M.S.M. Kong

The magic touch of creative fantasy: Turning C.G. animation into telling movies

C.M. Figueiredo

\section{Part VII Exhibitions}

Drawings \& paintings: "Pompeii colours and materials" M.J. Durão

Literature and video: "Borderlands"

M. Simonson \&T. Örn Karlsson 